\title{
Preface
}

\section{Neotropical catfish diversity: an historical perspective}

\author{
Carl J. Ferraris, Jr. and Roberto E. Reis
}

This issue of Neotropical Ichthyology is a collaborative effort between the Sociedade Brasileira de Ictiologia (SBI) and the All Catfish Species Inventory (ACSI) to bring to print reports of the discovery of new species of Neotropical catfishes. Herein, 28 new catfish species and one genus are described, and four of the included papers are generic revisions. More than 30 authors contributed to the 19 papers, and many of these studies were the result of research or collecting efforts that were supported by ACSI.

The All Catfish Species Inventory was initiated in 2003 with its primary goal being to inventory and describe the global diversity of catfishes, within a five-year period. The Inventory has received generous financial support from the U. S. National Science Foundation (DEB 0315963) as part of its Planetary Biodiversity Initiative. This support has allowed its investigators to conduct research and undertake collecting expeditions in poorly-explored parts of the world and to support the field work and research of a large number of catfish taxonomists throughout the world. Additional information on the goals of the ACSI, and the results to date, can be found on its web site at: http://clade.acnatsci.org/allcatfish.

Our understanding of the taxonomic diversity of Neotropical catfishes has been growing at an ever-increasing rate since the early days of modern biological nomenclature. Linnaeus (1758) included only five species of Neotropical catfishes, based primarily on the work of Gronovius (1754). Somewhat over a century later, the number of species known from South and Central America had increased to 305 (Günther, 1864) (see Table 1), most of which had been discovered in small collections sent out from the European colonies of northern South America. By the last decade of the $19^{\text {th }}$ Century, the total number of known catfish species had risen to 476 (Eigenmann \& Eigenmann, 1890). The $20^{\text {th }}$ Century heralded a dramatic increase in research on Neotropical fishes, and that increase was quickly reflected in a sizable increase in the number of reported catfish species, to 655, by Eigenmann (1910). More than 500 additional species were added to the list of Neotropical catfishes by Gosline (1945), in the next 35 years. Another 500 species had been named by the publication of most recent compilation of Neotropical fishes, CLOFFSCA (Reis et al., 2003), bringing the total to 1649. This reflects a growth in recorded species of somewhat over 1000 species in the past century, or approximately 100 per decade.

Since the initiation of ACSI in 2003, more than 100 additional Neotropical catfishes have been named, in addition to the 28 described in this issue. Thus, the rate of discovery of catfishes is currently more than three times the average annual rate over the past century. Several factors may have contributed to this increase in rate, including an increase in the number of taxonomists studying catfishes, more intensive exploration of the waterways of the South American continent, changing species concepts that, for the most part, tend to more finely discriminate populations. The rapid rate of species descriptions that we now see is likely to be sustained into the foreseeable future, if the necessary support continues to be available for the underlying collection and research activities. Complete and accurate documentation of the fish diversity of the Neotropics is a goal of both SBI and ACSI, and both organizations are proud to have contributed to that goal with this publication. 


\section{Literature cited}

Eigenmann, C. H. 1910. Catalogue of the fresh-water fishes of tropical and south temperate America. Pp. 375-511, In: Reports of the Princeton University expeditions to Patagonia 1896-1899, Zoology, vol. 3. Princeton University.

Eigenmann, C. H. \& R. S. Eigenmann. 1890. A revision of the South American Nematognathi or cat-fishes. Occasional Papers of the California Academy of Sciences, 1: 1-508.

Gosline, W. A. 1945. Catálogo dos nematognatos de água-doce da América do Sul e Central. Boletim do Museu Nacional. Nova série, Zoologia, 33: 1-138.

Gronovius, L. T. 1754. Museum Ichthyologicum, sistens Piscium indigenorum \& quorundam exoticorum, qui in Museo Laurenti Theodori Gronovii, J. U. D. adservantar, descriptiones, ordine systematico; accedunt nonnullorum exoticorum piscium icones, aeri incisae [vol. 1]. Theodorum Haak, Lugduni-Batavorum. 70 p., 4 pls.

Günther, A. 1864. Catalogue of the fishes in the British Museum, vol. 5. - Catalogue of the Physostomi, containing the families Siluridae, Characinidae, Haplochitonidae, Sternoptychidae, Scopelidae, Stomiatidae in the collection of the British Museum. Trustees, London. xxii $+455 \mathrm{p}$.

Linnaeus, C. 1758. Systema naturae per regna tria naturae, secundum classes, ordines, genera, species, cum characteribus, differentiis, synonymis, locis. Tomus I. Editio decima, reformata. Holmiae. ii +824 p.

Reis, R. E., S. O. Kullander, \& C. J. Ferraris, Jr. (eds). 2003. Check list of the freshwater fishes of South and Central America. Edipucrs, Porto Alegre. 729 p.

Table 1. Number of species of Neotropical catfishes, by family, listed in published compilations from 1864 to 2003. Family assignments of species and order of presentation of families follow CLOFFSCA, with a separate category of incertae sedis for species of the currently-unplaced genus Conorhynchos. As in CLOFFSCA, taxa listed as valid subspecies were counted separately in the relevant tallies. Counts followed by an asterisk indicate that the tally only included freshwater species, excluding both marine and estuarine taxa.

\begin{tabular}{|c|c|c|c|c|c|}
\hline & $\begin{array}{c}\text { Günther } \\
1864\end{array}$ & $\begin{array}{c}\text { Eigenmann \& } \\
\text { Eigenmann } \\
1890\end{array}$ & $\begin{array}{c}\text { Eigenmann } \\
1910\end{array}$ & $\begin{array}{c}\text { Gosline } \\
1945\end{array}$ & $\begin{array}{c}\text { Reis et al. } \\
2003 \\
\text { (CLOFFSCA) }\end{array}$ \\
\hline Diplomystidae & 1 & 1 & 1 & 2 & 6 \\
\hline Cetopsidae & 4 & 7 & 8 & 15 & 20 \\
\hline Aspredinidae & 9 & 15 & 22 & 31 & 36 \\
\hline Nematogenyidae & 1 & 1 & 1 & 1 & 1 \\
\hline Trichomycteridae & 15 & 31 & 65 & 139 & 171 \\
\hline Callichthyidae & 14 & 25 & 34 & 51 & 177 \\
\hline Scoloplacidae & 0 & 0 & 0 & 0 & 4 \\
\hline Astroblepidae & 6 & 7 & 23 & 39 & 54 \\
\hline Loricariidae & 81 & 148 & 208 & 426 & 673 \\
\hline Heptapteridae & 31 & 54 & 99 & 193 & 186 \\
\hline Pimelodidae & 50 & 42 & 55 & 79 & 83 \\
\hline Pseudopimelodidae & 6 & 6 & 12 & 23 & 26 \\
\hline Ariidae & 37 & 50 & $14 *$ & $19 *$ & 46 \\
\hline Doradidae & 27 & 42 & 58 & 73 & 74 \\
\hline Auchenipteridae & 22 & 45 & 51 & 86 & 91 \\
\hline Incertae sedis & 1 & 2 & 3 & 2 & 1 \\
\hline Totals & 305 & 476 & 655 & 1179 & 1649 \\
\hline
\end{tabular}

